\title{
Long-Term Results of Anterior versus Posterior Operations for Herniated Cervical Discs: Analysis of 6,000 Patients
}

\author{
George J. Dohrmann Joseph C. Hsieh \\ Section of Neurosurgery, University of Chicago Medical Center, Chicago, III., USA
}

\section{Key Words}

Cervical disc herniation - Cervical disc operations - Anterior cervical discectomy/fusion - Posterior cervical disc operations · Laminoforaminotomy · Keyhole facetectomy

\begin{abstract}
Objective: To analyze the long-term outcomes of anterior versus posterior approaches for cervical disc herniation. Methods: The records of 6,000 patients who had operations for cervical disc herniation (radiating arm pain and/or motor symptoms involving the upper extremity) and who had been followed for at least 2 years (mean: 7.1 years) were culled from the world literature and included in this analysis. The outcome (good/excellent, according to the patient) of anterior versus posterior surgery was compared. Results: Of the 6,000 patients, 2,888 (48.1\%) had anterior operations (anterior cervical discectomies, with or without fusion) and $3,112(51.9 \%)$ patients were operated on posteriorly (laminoforaminotomies/'keyhole' facetectomies). Although initially equal, in long-term follow-up, patients who had anterior operations had $80 \%$ good/excellent results, whereas patients with the posterior approach had $94 \%$ good/excellent results. The difference was significant $(p<0.05)$. Conclusion: The better long-term results with the posterior operation might be due to the more complete opening of the foramen for neural decompression at the time of the operation and thereafter.

(c) 2013 S. Karger AG, Basel
\end{abstract}

\section{Introduction}

Operations for cervical disc herniation have been done for decades [1-35]. The posterior approach was started by Spurling and Scoville in 1944 [22]. The anterior operation was begun in 1955 by Robinson and Smith [29] and a variation on the anterior approach was done by Cloward [3] 3 years later. Both operations were successful at relieving patients of radiating arm pain and motor and/or sensory symptoms. Most surgeons did either the anterior or the posterior approach and a few surgeons performed both operations. All surgeons reported that these operations were quite successful. There has not been a large study comparing the long-term results of anterior versus posterior operations. This study assessed long-term follow-up in patients operated anteriorly as well as those patients having posterior procedures.

\section{Subjects and Methods}

The records of 6,000 patients who had been operated upon for cervical disc herniation (radiating arm pain and sensory and/or motor symptoms involving the upper extremity) were culled from the world literature [1-35]. To be included in this study, the patients had to have been followed for 2 years or more. The outcomes (good/excellent), as assessed by the patient and doctor, were tabulated relative to patients operated anteriorly (with or without fu-

\begin{tabular}{ll}
\hline KARGER & $\begin{array}{l}\text { () 2013 S. Karger AG, Basel } \\
1011-7571 / 14 / 0231-0070 \$ 39.50 / 0 \quad \text { Karger }\end{array}$ \\
$\begin{array}{l}\text { E-Mail karger@karger.com } \\
\text { www.karger.com/mpp }\end{array}$ & $\begin{array}{l}\text { This is an Open Access article licensed under the terms of the } \\
\text { Creative Commons Attribution-NonCommercial 3.0 Un- } \\
\text { ported license (CC BY-NC) (www.karger.com/OA-license), } \\
\text { applicable to the online version of the article only. Distribu- } \\
\text { tion permitted for non-commercial purposes only. }\end{array}$
\end{tabular}

George J. Dohrmann, MD, PhD

Section of Neurosurgery-MC3026, University of Chicago Medical Center

5841 South Maryland Avenue

Chicago, IL 60637 (USA)

E-Mail GJDMDPHD@gmail.com 
sion) and those operated posteriorly. Patients classified as 'good/ excellent' had relief of symptoms and no recurrence of symptomatology. A statistical comparison was then made between the two groups ( $\mathrm{t}$ test indicating $\mathrm{p}$ values).

\section{Results}

Of the 6,000 patients analyzed, 2,888 (48.1\%) were operated on anteriorly with discectomy, with or without fusion. Laminoforaminotomies/keyhole facetectomies with removal of the nerve root compression were done on 3,112 (51.9\%) patients.

Disc herniations were at multiple cervical levels; however, the majority occurred at C5-6 and C6-7. Specifically, the disc herniations occurred as follows: $\mathrm{C} 3-4: 3 \%$, C4-5: 9\%, C5-6: 39\%, C6-7: 46\% and C7-T1: 3\% (table 1).

The 6,000 patients were followed for a mean of 7.1 years. Those operated on anteriorly were followed for 5.9 years, while the patients operated on posteriorly were followed for 8.5 years. In patients with anterior cervical discectomies, results were the same with or without fusion. The overall good/excellent results were rated $87 \%$, while anterior operations were $80 \%$ and posterior procedures were $94 \%$. The difference was statistically significant $(\mathrm{p}<$ 0.05).

\section{Discussion}

Operations for cervical disc herniation are some of the most gratifying operations done by neurosurgeons. The posterior operation for cervical disc herniation was the first of the two general operations done as devised by Spurling and Scoville [22]. Decompression of the cervical nerve root, by removing the herniated portion of the disc, gave relief from the radiating arm pain as well as the motor and/or sensory symptomology. The procedure was refined by Scoville to the keyhole facetectomy [26]. Patients had immediate relief of the symptomology.

In 1955, Robinson and Smith [29] introduced the anterior approach to cervical disc herniation, which involved discectomy with interbody fusion. In 1958, Cloward [3] published his anterior approach, including his method of fusion. Many series of such anterior operations have been published, and all authors have noted gratifying results (table 2).

Over the ensuing years the popularity of the anterior operation, with or without fusion, has greatly increased.
Instrumentation further increased the popularity of anterior discectomy as the fusion procedure became simplified. Fewer surgeons performed the posterior operation for cervical disc herniation; however, surgeons still noted how successful that procedure was as well (table 3 ).

Our analysis showed that most surgeons considered both operative procedures - anterior and posterior - to give good results in treating cervical disc herniation/cervical radiculopathy. However, the question for which we wished to find the answer was how similar are the longterm results of the two methods, and if there was any significant difference between the two.

Unlike previous series (anterior or posterior), which for the most part comprised a range of less than $100 \mathrm{pa}-$ tients to hundreds of patients, the present analysis of 6,000 patients operated on for cervical disc herniation/ cervical radiculopathy had many more numbers of operations, Equally, the follow-up was long, averaging almost 6 years in the anterior group and 8 years in the posterior group, thereby yielding a greater percentage of good/excellent results with the posterior technique (94\%) than the anterior one $(80 \%)$.

The findings were unexpected because initially we assumed that good/excellent results would be similar in both methods. The difference cannot be ascribed to small sample size, as this series had 6,000 patients. Mean followup times were significant in both groups. Initially, over 4,000 patients were studied and, because of the unexpected results, the study was expanded to 6,000 patients. The results were the same. It is inconceivable that one group of patients/surgeons graded the outcome of 'anterior patients' differently relative to 'posterior patients'. Any variations would have been insignificant because of the large number of patients in each group; therefore, the difference is real.

A difference of $14 \%$ in 6,000 patients is significant $(\mathrm{p}<0.05)$. Certainly, with a series of this size, the difference is due to something other than chance. The probable explanations for such a difference may be that the posterior operation visualizes the cervical nerve root more 
Table 2. Anterior approach

\begin{tabular}{llll}
\hline Authors & $\begin{array}{l}\text { Number of } \\
\text { patients }\end{array}$ & $\begin{array}{l}\text { Mean follow-up, } \\
\text { years }\end{array}$ & $\begin{array}{l}\text { Good/excellent } \\
\text { results, } \%\end{array}$ \\
\hline Dan [4], 1998 & 476 & 3.6 & 89 \\
Ruetten et al. [23], 2008 & 100 & 2 & 94 \\
Dowd and Wirth [5], 1999 & 84 & 4.5 & $98^{1}$ \\
Gore and Sepic [6], 1984 & 146 & 3.3 & 78 \\
Gore and Sepic [7], 1998 & 50 & 21 & 84 \\
Hamburger et al. [8], 2001 & 249 & 12.2 & 78 \\
Klaiber et al. [13], 1992 & 61 & 6.7 & 87 \\
Hubach [11], 1994 & 179 & 10.4 & 84 \\
Lunsford et al. [15], 1980 & 253 & 4 & 67 \\
Martin et al. [16], 1999 & 317 & 2.8 & not given \\
Rao et al. [20], 2008 & 34 & 4 & 76 \\
Wirth et al. [33], 2000 & 50 & 4.4 & 96 \\
Watters and Levinthal [32], 1994 & 62 & 6 & 95 \\
Nandoe Tewarie et al. [18], 2007 & 456 & 7 & 68 \\
Schlosser et al. [25], 2006 & 219 & 6.4 & not given \\
van den Bent et al. [31], 1996 & 81 & 2 & 73 \\
Yue et al. [34], 2005 & 71 & 7.2 & 82 \\
Overall & 2,888 & 5.9 & 80 \\
\hline
\end{tabular}

1 'Helped' by the procedure (phone interview).

Table 3. Posterior approach

\begin{tabular}{llll}
\hline Authors & $\begin{array}{l}\text { Number of } \\
\text { patients }\end{array}$ & $\begin{array}{l}\text { Mean follow-up, } \\
\text { years }\end{array}$ & $\begin{array}{l}\text { Good/excellent } \\
\text { results, \% }\end{array}$ \\
\hline Scoville et al. [26], 1976 & 175 & $21^{1}$ & 95 \\
Henderson et al. [9], 1983 & 736 & 8 & 92 \\
Clarke et al. [2], 2007 & 303 & 7 & 96 \\
Jagannathan et al. [12], 2009 & 162 & 6.4 & 95 \\
Korinth et al. [14], 2006 & 292 & 6 & 97 \\
Zeidman and Ducker [35], 1993 & 172 & 2 & 97 \\
Tomaras et al. [30], 1997 & 200 & 2 & 93 \\
Ruetten et al. [23], 2008 & 100 & 2 & 97 \\
Wirth et al. [33], 2000 & 22 & 5.3 & 100 \\
Hilton [10], 2007 & 222 & 2.2 & 95 \\
Caglar et al. [1], 2007 & 84 & 7.8 & 96 \\
Murphey et al. [17], 1973 & 644 & up to 28 & 91 \\
Overall & 3,112 & 8.5 & 94 \\
\hline
\end{tabular}

${ }^{1} 5-33$ years.

completely; however, good visualization of the nerve root is obtained with the anterior operation as well; therefore, this explanation does not satisfactorily account for the statistically significant difference. Another explanation may be that the nerve root in the foramen is decompressed over a greater distance. Perhaps the extensive opening of the bony foramen, converting it from a bony 'tunnel' into a bony 'trough', decreased the possibility of nerve root compression from future disc material or future compression from osteophytic growth, narrowing the foramen. Further studies should focus on this to help elucidate the reason(s) for the difference. 


\section{Conclusion}

In the 6,000 patients with long-term follow-up (mean: 7.1 years), those patients operated on posteriorly had a higher percentage of good/excellent results than those who had been operated on anteriorly.

\section{Acknowledgments}

One of the authors, Professor George J. Dohrmann, during his neurosurgical residency rotation had the opportunity to observe Dr. W.B. Scoville's technique and has also had the opportunity to study his long-term patient follow-up. Dr. Scoville's results, obtained prior to the advent of MRI and CT scanning, are an impressive $95 \%$ good/excellent results in patients followed up from 5 to 33 years.

\section{Disclosure Statement}

\section{References}

1 Caglar YS, Bozkurt M, Kahilogullari G et al: Keyhole approach for posterior cervical discectomy: experience on 84 patients. Minim Invasive Neurosurg 2007;50:7-11.

2 Clarke MJ, Ecker RD, Krauss WE et al: Same segment and adjacent-segment disease following posterior cervical foraminotomy. J Neurosurg Spine 2007;6:5-9.

3 Cloward RB: The anterior approach for removal of ruptured cervical disks. J Neurosurg 1958; 15:602-617.

-4 Dan NG: Anterior cervical graftless fusion for soft disc protrusion. A review of 509 disc excisions in 476 patients. J Clin Neurosci 1998;5: 172-177.

5 Dowd GC, Wirth FP: Anterior cervical discectomy: is fusion necessary? J Neurosurg 1999;90(suppl 1):8-12.

6 Gore DR, Sepic SB: Anterior cervical fusion for degenerated or protruded discs. A review of one hundred forty-six patients. Spine 1984; 9:667-671.

7 Gore DR, Sepic SB: Anterior discectomy and fusion for painful cervical disc disease. A report of 50 patients with an average follow-up of 21 years. Spine 1998;23:2047-2051.

8 Hamburger C, Festenberg FV, Uhle E: Ventral discectomy with PMMA interbody fusion for cervical disc disease. Long-term results in 249 patients. Spine 2001;26:249-255.

9 Henderson CM, Hennessy RG, Shuey HM, et al: Posterior-lateral foraminotomy as an exclusive operative technique for cervical radiculopathy: a review of 846 consecutively operated cases. Neurosurgery 1983;13:504-512.

10 Hilton DL Jr: Minimally invasive tubular access for posterior cervical foraminotomy with three-dimensional microscopic visualization and localization with anterior/posterior imaging. Spine J 2007;7:154-158.

$\$ 11$ Hubach PC: A prospective study of anterior cervical spondylosis in intervertebral disc disorders. Eur Spine J 1994;3:209-213.

-12 Jagannathan J, Sherman JH, Szabo T, et al: The posterior cervical foraminotomy in the treatment of cervical disc/osteophyte disease: a single-surgeon experience with a minimum of 5 years clinical and radiographic follow-up. J Neurosurg Spine 2009;10:347-356.
13 Klaiber RD, von Ammon K, Sarioglu AC: Anterior microsurgical approach for degenerative cervical disc disease. Acta Neurochir 1992;114:36-42.

14 Korinth MC, Kruger A, Oertel MF, et al: Posterior foraminotomy or anterior discectomy with polymethyl methacrylate interbody stabilization for cervical soft disc disease: results in 292 patients with monoradiculopathy. Spine 2006;31:1207-1214.

15 Lunsford LD, Bissonette DJ, Jannetta PJ, et al: Anterior surgery for cervical disc disease. Part 1.Treatment of lateral cervical disc herniation in 253 cases. J Neurosurg 1980;53:1-11.

16 Martin GJ, Haid RW Jr, MacMillan M, et al: Anterior cervical discectomy with freezedried fibula allograft. Overview of 317 cases and literature review. Spine 1999;24:852-859.

17 Murphey F, Simmons JC, Brunson B: Ruptured cervical discs, 1939 to 1972 . Clin Neurosurg 1973;20:9-17.

18 Nandoe Tewarie RD, Bartels RH, Peul WC: Long-term outcome after anterior cervical discectomy without fusion. Eur Spine J 2007; 16:1411-1416.

19 Radhakrishnan K, Litchy WJ, O’Fallon WM, et al: Epidemiology of cervical radiculopathy. A population-based study from Rochester, Minnesota, 1976 through 1990. Brain 1994; 117:325-335.

20 Rao PJ, Christie JG, Ghahreman A, et al: Clinical and functional outcomes of anterior cervical discectomy without fusion. J Clin Neurosci 2008; 15:1354-1359.

21 Riew KD, Cheng I, Pimenta L, et al: Posterior cervical spine surgery for radiculopathy. Neurosurgery 2007;60:S57-S63.

22 Spurling RG, Scoville WB: Lateral rupture of the cervical intervertebral discs. A common cause of shoulder and arm pain. Surg Gynecol Obstet 1944;78:350-358.

23 Ruetten S, Komp M, Merk H, et al: Full-endoscopic cervical foraminotomy for operation of lateral disc herniations using $5.9-\mathrm{mm}$ endoscopes. A prospective, randomized, controlled study. Spine 2008;33:940-948.
24 Russell SM, Benjamin V: Posterior surgical approach to the cervical neural foramen for intervertebral disc disease. Neurosurgery 2004;54:662-666.

25 Schlosser MJ, Schwarz JP, Awad JN, et al: Anterior cervical discectomy and fusion with allograft and anterior plating. A report on 219 patients/469 levels with a minimum of 2-year follow-up. Neurosurg Quart 2006;16:183186.

26 Scoville WB, Dohrmann GJ, Corkill G: Late results of cervical disc surgery. J Neurosurg 1976;45:203-210.

27 Scoville WB, Whitcomb BB: Lateral rupture of cervical intervertebral discs. Postgrad Med 1966;39:174-180.

28 Smith GW, Robinson RA: The treatment of cervical spine disorders by anterior removal of the intervertebral disc and interbody fusion. J Bone Joint Surg 1958;40A:607-623.

29 Robinson RA, Smith GW: Antero-lateral disc removal and interbody fusion for cervical disc syndrome. Bull Johns Hopkins Hosp 1955;96: 223-224.

30 Tomaras CR, Blacklock JB, Parker WD, et al: Outpatient surgical treatment of cervical radiculopathy. J Neurosurg 1997;87:41-43.

31 van den Bent MJ, Oosting J, Wouda EJ, et al: Anterior cervical discectomy with or without fusion with acrylate. A randomized trial. Spine 1996;21:834-839.

32 Watters WC, Levinthal R: Anterior cervical discectomy with and without fusion: results, complications and long-term follow-up. Spine 1994;19:2343-2347.

33 Wirth FP, Dowd GC, Sanders HF, et al: Cervical discectomy. A prospective analysis of three operative techniques. Surg Neurol 2000; 53:340-348.

34 Yue W-M, Brodner W, Highland TR: Longterm results after anterior cervical discectomy and fusion with allograft and plating. A 5- to 11-year radiologic and clinical follow-up study. Spine 2005;30:2138-2144.

35 Zeidman SM, Ducker TB: Posterior cervical laminoforaminotomy for radiculopathy: review of 172 cases. Neurosurgery 1993;33:356362 